UDC 811.111'342.1:792.028

DOI https://doi.org/10.32999/ksu2663-3426/2020-2-7

\title{
PROSODIC ASPECTS OF INTERNAL MONOLOGICAL ACTING IN FILM DISCOURSE
}

\author{
Olinchuk Viktoriia Vladimirovna, \\ Candidate of Philological Sciences, Associate Professor, \\ Associate Professor at the Department of English № 2 \\ National University "Odessa Maritime Academy" \\ anglophon@gmail.com \\ orcid.org/0000-0003-1472-2998 \\ Tykhonina Svitlana Ivanovna, \\ Candidate of Philological Sciences, Associate Professor, \\ Associate Professor at the Department of English № 2 \\ National University "Odessa Maritime Academy" \\ s_tykhonina@ukr.net \\ orcid.org/0000-0001-6289-0529
}

The immediate aim of our research work is to establish the correlation between the gender age and psychological state of the speaker and their impact on the prosodic arrangement of his speech. The work dwells on the observation of the notion of monological speech in the field of cinematic discourse and linguistics; the variety of functional styles introduced in the monologues. The practical piece deals with the analysis of the stylistic and prosodic markers of actor's monological speech on various levels. The research employed not only the stylistic means of expression but included the investigation of the prosodic components of pitch level, loudness and tempo. Within the auditory analysis these components revealed the essence of the chosen topic and proved the hypothesis of the correlation of the protagonist's age, his psychological state, his emotions and the peculiarities of his speech. The research contemplates methodology and results of both auditory and electro-acoustic analyses of the monologues extracted from the film authentic language of which is American English. Modern methods of speech analysis carried out by means of computer program PRAAT for the ecserps of inner monologues in actor's realization proved the suggested hypothesis. Linguistic interpretation of the results of the instrumental analysis is provided here as well.

Key words: monological speech, film discourse, actor speech, stylistic peculiarities, gender, age, prosodic components, instrumental analysis.

\section{ПРОСОДИЧНІ АСПЕКТИ АКТОРСЬКОГО МОНОЛОГІЧНОГО МОВЛЕННЯ В КІНЕМАТОГРАФІЧНОМУ ДИСКУРСІ}

\author{
Олінчук Вікторія Володимирівна, \\ кандидат фрілологічних наук, доцент, \\ доцент кафедри англійської мови № 2 \\ Національний університет «Одеська морська академія» \\ anglophon@gmail.com \\ orcid.org/0000-0003-1472-2998 \\ Тихоніна Світлана Іванівна, \\ кандидат фрілологічних наук, доцент, \\ доцент кафредри англійської мови № 2 \\ Національний університет «Одеська морська академія» \\ s_tykhonina@ukr.net \\ orcid.org/0000-0001-6289-0529
}

\footnotetext{
Робота присвячена аналізу стилістичних і просодичних маркерів монологічного мовлення персонажа з бельгійської наукової драми “Mr. Nobody". Аутентична мова кінокартини - американська англійська. Головною метою дослідження є встановлення кореляції між віком і психологічним станом героя та їх впливом на стилістично-просодичне аранжування його мовлення. Окремо аналізуються загальні лінгвістичні особливості монологічного мовлення персонажа у виконанні актора (фонетичні, лексичні, синтаксичні), які належать до кожного віку Немо. На фонетичному рівні здійснюються аудиторський та електроакустичний аналізи найбільш експресивних монологів
} 
Немо у віці 9, 16, 34 та 118 років, включаючи такі просодичні компоненти: висотний рівень (ЧОТ), гучність (інтенсивність), темп мовлення. Фоностилістичний аналіз виявив різноманітність стилістичних прийомів, реалізованих у мовленні Пана Ніхто. За результатами перцептивного аналізу ми дійшли певних висновків, що репліки підлітка Немо вирізняються максимальною гучністю і становлять 93\%. Максимальний темп мовлення притаманний Немо у віці 34 роки і становить 55\%. Працюючи телеведучим, він звучить упевнено й авторитетно, намагаючись зацікавити аудиторію й упевнити у своїх словах. Мінімальна гучність ілюструє монологи старого Немо і становить 80\% загалом. Мінімальний темп є типовим для похилої людини, яка промовляє слова повільно, розмірковуючи над своїми вчинками й переосмислюючи свій життєвий шлях. Максимальний висотний рівень (60\%), із яким говорить Немо, відображає його депресивний психологічний стан. Він жалкує про речі, які не встиг зробити за свою юність. У процесі електроакустичного аналізу виявлено таку тенденцію: мінімальна чОТ і мінімальна інтенсивність мовлення характерні для монологів старого Немо, засмученого та пригніченого, що становить 60 Ги і 45 Дб відповідно; тоді як максимальна ЧОТ у 220 Ги реалізована в монолозі спостережливого восьмирічного Немо, а максимальна інтенсивність проявляється в мовленні підлітка, сповненого юнацького максималізму та самовпевненості. Як результат дослідження варто відмітити, що вік Немо прямо впливає на стиль його мовлення, а емоційність його слів залежить від психологічного стану, у якому він перебуває на момент мовлення. Вік та емоції визначають експресивність і яскравість монологів персонажа в просодичних і стилістичних параметрах їх акторської реалізації.

Ключові слова: монологічне мовлення, акторське мовлення, кінематограффічний дискурс, стилістичні прийоми, гендер, вікові особливості, просодичні параметри, інструментальний аналіз.

\section{Introduction}

The present research is dedicated to the analysis of stylistic and prosodic markers of the protagonist's monological speech extracted from a Belgian science fiction-drama "Mr. Nobody" directed by a famous Belgian film director Jaco Van Dormael in 2009 at Pan-Européenne film production and publishing company in France and starring American actors Jared Leto, Sarah Polley, Diane Kruger and Linh Dan Pham. "Mr. Nobody" is a tale that envelopes $141 \mathrm{~min}$ utes and spans different time zones of the 20th and 21 st centuries. The film juxtaposes several genres in itself: science fiction, fantasy and love story and serves as the material of the analysis. The authentic language of the film is American English.

Mr. Nobody tells the life story of Nemo Nobody (Leto), a 118 year-old man who is the last mortal on Earth after the human race has achieved quasi-immortality. Nemo tells his story in segments to a young reporter and to his psychiatrist. Nobody refers to his three main loves and to his parents' divorce and subsequent hardships in his life. The film utilizes non-linear plot progression and the many-worlds interpretation to tell the story of Nemo aged 9, 16, 34 and 118 .

The overall sounding of the monologues includes 50 minutes. The experimental corpus involves 4 most prominent monologues in 20 minutes total sounding.

The subject of the present paper is stylistic and prosodic markers of monological speech of Mr. Nobody.

The object of the investigation is the extracted monologues of the protagonist - Nemo Nobody.

The main goal of our research work is to establish the correlation between the gender age and psychological state of the speaker and their impact on the prosodic arrangement of his speech.

Proceeding from the aim of the investigation the following tasks are to be solved:

- to observe theory of monological speech in modern linguistics and in the field of cinematic discourse that will prompt to select the most meaningful monologues for the further analysis;

to investigate general stylistic and prosodic markers of monological speech, i.e. phonetic, syntactical and lexical referring to certain age of Nemo Nobody separately;

- to accomplish the auditory and electro-acoustic analyses of the most prominent monologues uttered by Nemo at the age of 9, 16, 34 and 118, considering the following prosodic components: pitch level, loudness and tempo of speech;

- to set the correlation between the age characteristics of Nemo, his emotions and the peculiarities of his speech.

At the present stage of the analysis three linguistic levels are taken into consideration: phonetic, lexical and syntactical.

The subject of the investigation is actual because of the abundance of various stylistic devices belonging to different linguistic levels that reveal the impact of gender age characteristics on the psychological state of the protagonist which prompts the audience to penetrate into the inner world of Nemo Nobody and make up their own mind on the life choice.

Both stylistic and prosodic markers of monological speech are analyzed in the present paper. The investigation concludes with the results of the auditory and electro-acoustic analyses and the hypothesis proof.

2. The notion of monological speech in the field of cinematic discourse 
As the subject of the research work dwells on the investigation of monological speech of the protagonist, the task of theory observation on this issue is of essential importance.

Monologue and dialogue are often conceived as two opposite phenomena and every dramatic utterance is assigned to one of these categories. There are, of course, situational and structural differences between these. The situational criterion for monologue is that there is no addressee, at least not on stage. The structural criterion refers to the length and autonomy of a particular speech. Monologue has long individual utterances and is presented by one speaker only in comparison with dialogue. There is only one semantic direction in monologue. Professor V.A. Kukharenko notifies: "Inner speech and the pronounced one complement each other, creating a single part of the protagonist, characterizing him through his own consciousness and speech system" (Kukharenko 2002: 200).

Interior monologues involve a character externalizing their thoughts so that the audience can witness experience that would otherwise be mostly internal. In contrast, a dramatic monologue involves one character speaking to another character. Monologues can also be divided along the lines of active and narrative monologues. In an active monologue a character is using his speech to achieve a clear goal. Narrative monologues simply involve a character telling a story and can often be identified by the fact that they are in the past tense.

What absolutely distinguishes the interior monologue from other representations of consciousness is its prohibition of expressed statements by a narrator that the character is in fact thinking of perceiving. The words purport to be exactly those that pass through his or her mind, or their surrogates, if the thoughts are perceptions. Linguist V. A. Kukharenko clarifies: "... interior speech is notable for the extreme development of associativity. Free, often accidental type of associations, which pull distant and diverse phenomena together, and the compact type of message are not an obstacle for comprehension, for the recipient and the sender is the same person" (Kukharenko 2002: 189).

Interior monologue is marked by syntax: it ascribes present tense verbs and first person pronoun-reference to the thinking character (or the implication of these where the syntax is truncated). Stream of consciousness goes beyond syntax: it constrains the arrangement of semantic elements according to the principle of free association. There is no reason why the two must co-occur (though they usually do). Authors readily combine the free associative principle with the use of the epic preterite, tags, and so on. Stream of consciousness can be an ordering principle even in dialogue. Or contrarily a sustained interior monologue can show content development of a highly purposive, teleological, "controlled-associative" sort.

As far as the paper deals with the investigation of the monologues in cinematograph, i.e. in the particular film, it should be mentioned about the role of the monologue in the cinema in order to get a clear view on the subject.

The cinema uses the interior monologue and stream of consciousness infrequently, and it is interesting to consider why. Some theorists suggest the influence of the behaviorist school of modern fiction, in which language is generally depreciated, in particular the language of thinking. More likely, since films show everything, offscreen voices in general have come to be thought obtrusive and inartistic, and those speaking in truncated syntax and free-associative patterns particularly so. Professor of Rhetoric at the University of California, Seymour Chatman, clarifies: «Truncated syntax is a convention supposed to suggest either that the mind tends to grammatical shortcuts in ordinary musing, or that there exists a phenomenon like "prespeech" or "preverbal" mental activity that does not follow the normal rules of grammar (Chatman 1978:188).

The main function of the monologue embedded in the film lies in conveying a particular piece of information to the audience. The speaker's aim is to express his viewpoint on some situation and to make his attitude towards his words clear and meaningful to the addressee. Some of the monologues tend to be spontaneous as a result of mental activity of the protagonist.

The speaker has his own speech experience, but the instantaneousness of creating and realizing the "meaning program" in the conditions of the free spontaneous speech complicates the formation of this or that speech production.

Depending on the aim of the speaker and the intonation he uses in pronouncing his words in the film, monologues can be divided into emphatic and unemphatic. When the speaker's aim is to express only the intellectual content of the thought, i.e. when he does not mean to express his own attitude or emotions, and does not wish to give any particular prominence to any part of the utterance, his speech may be called unemphatic, i. e. not prominent.

Cinematic discourse is a multicode cognitive-communicative formation, a combination 
of various semiotic units in their inseparable unity that is characterized by the coherence, integrity, completeness and addressness. Linguist I. Lavrinenko at Kharkov University informs: "Cinematic discourse is expressed in the verbal, nonverbal (including cinematographic) signs according to the plot of collective authors, and is structured by the means of communicative role change. It is fixed on the material object and is meant for the reproduction (playback) on the screen and for the audio-visual perception by the audience" (Lavrinenko 2012: 42).

\section{The stylistic and prosodic markers of monological speech}

The investigation of the stylistic and prosodic markers of Nemo's speech uppermost reveals the colloquial - free - character of the protagonist's irreciprocal monological communication, thus, indicating the interrelation between his mood, feelings, thoughts, and the age in which he abides.

\section{0:21:28-00:22:05 (about the life choice)}

Nemo aged 8: "If you mix the mashed potatoes and sauce, you can't separate them later. It's forever. The smoke comes out the daddy's cigarette but it never goes back in. We cannot go back. That's why it's hard to choose. You have to make the right choice. As long as we don't choose - everything remains possible" (Mr.Nobody : 2009).

As far as syntactic peculiarities are concerned, it should be mentioned that the speaker uses the Present Simple Tense in his speech. According to their length sentences in the monologue under review vary from short to medium. Short sentences play a more meaningful role in the protagonist's speech accentuating the attention of the audience on the very sense of what is said.

The modal verb "have" is accentuated here which demonstrates its significance in the speech of Nemo ("You have to make the right choice"). As if applying to the audience, Nemo stresses the verb "have" to make a special emphasis on its sense. Everything remains possible until one makes a choice. And this choice should be the right one least there would follow further regret.

"As long as we don't choose - everything remains possible", - the following phrase is considered to be the most prominent in the chosen monologue, as it conveys the main idea of the film. Any choice in human's life can become vital and can influence the further coming events on his life path.

Nemo sounds confident and firm, as if giving the audience some piece of important information, though he doesn't impose his will on them.
On the contrary, his words lead the addressee to his own meditations, or ideas.

The sentence consists of two sense-groups. The syllables are pronounced with the Level Head combined with the Low Fall.

The next step of the analysis of the given monologue implies the analysis of stylistic devices applied in Nemo's speech.

Phonemic structure of the word proves to be important for the creation of expressive and emotive connotations. The stylistic use of phonemes and their graphical representation is illustrative in the use of alliteration in the given abstract. It can be seen that a special accent is made on the repetition of the consonant $\mathrm{s}$ sounding both as repetitive [s] and [z].

Lexical stylistic devices are presented in the use of lexical repetition of the word "choose", which occurs twice in the given extract and functions in the monologue as a key-word, bearing the top meaning of the whole film. The word "choice" is employed jointly with its relative word "choose" in order to manifest the idea of human's life choice. Verbal metaphor is given in the phrase: "The smoke comes out... it never goes back in" which is based on the similarity between the actions of animate and inanimate objects.

Syntactical stylistic markers involved in the monologue comprise the use of parallel construction, asyndetic sentences and attachment. The use of parallel construction to be seen here is represented by two parallel verbs (The smoke comes out the daddy's cigarette but it never goes back in) and demonstrate two simultaneous actions.

The arrangement of sentence members and the completeness of sentence structure necessarily involve various types of connection used within the sentence or between sentences. The abstract includes two types of connection - asyndeton ("We cannot go back. That's why it's hard to choose. You have to make the right choice.") and attachment( "If you mix the mashed potatoes and sauce, you can't separate them later. It's forever") (Mr. Nobody : 2009).

No conjunctions are found: asyndeton is used for conveying time-divided and/or space-divided stages of one action, interrelated with each other ... in this way the utterance acquires an accurate and firm rhythm». Thus, asyndeton helps to create the effect of energetic, active speech here. And attachment creates the effect of an afterthought connected with the beginning of the utterance.

01:03:19-01:03:50 (about dreams and plans on future life)

Nemo aged 9: [narrating] "On that day, I would make a lot of various decisions". 
Nemo aged 16: "One: I will never leave anything to chance again. Two: I will marry the girl on my motorcycle. Three: I'll be rich. Four: we'll have a house. A big house, painted yellow, with a garden. And two children: Paul and Michael. Five: I'll have a convertible. A red convertible! And a swimming pool! I'll learn to swim! Six: I will not stop until I've succeeded!" (Mr. Nobody: 2009).

The present monologue is prominent for the abundance of numerals, as the speaker enumerates all his dreams (wishes) that he would like to implement in future. Nemo's speech is presented in the Tense of Future Simple. The protagonist enumerates all his dreams and plans, using personal pronoun "I", which emphasizes and identifies his role in life, and the auxiliary verb "will". The verbs used together with the auxiliary "will" express intentions of Nemo: will have, will not stop, will learn, will marry. "I will not stop until I've succeeded!" (Mr. Nobody: 2009) - are the most prominent words exclaimed by Nemo, who sounds so confident and ambitious in the present abstract. "Exclamation informs not only about the emotive tension, but also introduces the additional semantic information".

Syllables are pronounced with the Descending Stepping Head combined with the Low Fall on the medium pitch level. The speaker pronounces every single word loudly, emphasizing not only the words themselves, but the very sense of them either. He doesn't hurry, and conveys his thoughts using normal tempo, which implies his confidence in his own efforts.

Alliteration employed on the phono-graphical level of stylistics is found in the frequent application of consonant "l", it produces the effect of rhythmicality of the utterance. The morphological level is represented by the stylistic device of morphological repetition proceeded in the reiteration of the stem "swim" ("And a swimming pool! I'll learn to swim”).

Simple affective epithets (Lexical level) "a red convertible" and "a big house" convey the emotional evaluation of the objects by Nemo, making his dreams more colorful and creating a brighter image in the minds of the audience. Phrase-epithet "the girl on my motorcycle" adds to the originality of the chosen monologue.

The conspicuous feature of this monologue is frequent use of different types of repetition on the syntactical level. Successive repetition is employed together with parallel constructions, thus manifesting enumeration (I will never leave anything to chance again. I will marry the girl on my motorcycle. I'll be rich. I'll have a con- vertible! I'll learn to swim! I will not stop until I've succeeded!). This is the most emphatic type of repetition which signifies the peak of emotions of young Nemo. The protagonist makes an accent on his dreams, applying epiphoric repetition in the words: "I'll have a convertible. A red convertible!" and ordinary repetition in the phrase: "... we'll have a house. A big house, painted yellow".

The stylistic device of attachment is mainly to be found in various representations of the voice of the personage. In the chosen extract attachment "a big house, painted yellow, with a garden" reveals the second part of the phrase to be an afterthought. That makes the protagonist's speech more significant, especially due to the pauses he makes while pronouncing these words.

As for the lexico-syntactical level, it is necessary to mention the application of the stylistic device of quantitative climax. The intensification of Nemo's emotions is represented in a construction consisting of many steps. The highest point of his emotions is expressed in the last sentence: I will not stop until I've succeeded!

\section{2:13:45-02:14:06 (about life itself)}

Nemo aged 118: "I'm not afraid of dying. I'm afraid I haven't been alive enough. It should be renown - every schoolroom blackboard. Life is a playground. Or nothing”.

The usage of the word "afraid" is prominent in this monologue. In the first sentence it is used in the category of the Gerund ("not afraid of dying"), in the second one we can see it being used as a predicative with the auxiliary "to be" in the $1^{\text {st }}$ person, singular, the Present Simple Tense. Then come the combination of the personal pronoun and the compound nominal predicate. So the pattern is the following: auxiliary + predicative + personal pronoun + compound nominal predicate.

Pronouncing the words "afraid" and "not afraid" Nemo Nobody makes a contrast between two objects - his intrepidity towards the death and his fear of living the aimless life. The repetitive [d] falls into the application of deliberate alliteration (on the phono-graphical level) to make the idea of aimless lapse of life manifest ("I'm not afraid of dying. I'm afraid I haven't been alive enough").

In the third sentence the modal verb "should" is mentioned and expresses the modal notion of the certainty and necessity of the action. It is also used here as part of the compound verbal predicate ("should be renown").

The words "dying", "alive" and "life" function in the present monologue as key words revealing the concept of the film about the life choice in human's life. 
The most conspicuous phrase in the chosen extract ("Life is a playground. Or nothing") expresses the main idea the speaker wants to share with the audience. From the viewpoint of phonetics the two sentences are divided into 2 short sense groups. Syllables are pronounced with the Level Head combined with the High Fall in the first case and the Low Fall in the other. The speaker utters the words with sorrow in his voice, as his life is coming to an end and he hasn't done many important things yet. The pauses are short but significant which gives the audience a chance to overthink every single idea of Nemo. And the use of High Fall in the phrase "Life is a playground" conveys the main sense of the analyzed monologue.

The following monologue is notable for the abundance of various stylistic devices on different levels.

On the lexical level metaphor "Life is a playground" is employed, since Mr. Nobody compares his existence to a sort of a territory which belongs to each child. One can play there any game he wants without being driven away. Playground is the territory of every single child. To be more certain, the protagonist draws a parallel between life and a playground. Everyone lives his own life. And Nemo lives his own life as if playing a game. The following metaphor discloses the most important idea that permeates the whole film and functions in the monologue as a key word.

The syntactical level abounds in repetition and detachment. The extract of the monologue opens with the anaphoric repetition of the word: "afraid" that reveals the fair feelings of the protagonist, who makes a review of his whole life in order to discover or, to be more right, to find acts he didn't manage to fulfill during his life.

In the two given sentences: "Life is a playground. Or nothing", both parts refer to the same idea; they are logically connected, but syntactically separated. The following way of setting a full stop between two logical parts which could be considered as one whole sentence is falls to be the stylistic device of detachment. The protagonist wants to emphasize the meaning of the last sentence, as it is the most important thing he said. It's the fair gist of everything said earlier.

Every single sentence in the given monologue makes up a certain gradual rise of a chain of emotionally colored sentences. And in the conclusive sentence emotionof regret acquires logical importance; it is accumulated only to be unexpectedly broken and brought to a sudden cadence, which reveals a certain stress on the very last phrase - "nothing". All the thoughts are summed up in one word: ("Life is a playground. Or nothing"). This example demonstrates the stylistic device at the lexico-syntactical level - anticlimax.

As can be seen from the above, the abundance and tension of emotions in Nemo's monologues result in the variety of stylistic and prosodic figures of speech applied in the observed extracts.

\section{Methodology and results of the instru- mental analysis}

In order to find out the dependency of prosodic peculiarities of Nemo's speech from his age and emotions (psychological state) the need to accomplish the auditory analysis arose. The analysis was accomplished according to the methodology of the Chair of Theoretical and Applied Phonetics at I.I. Mechnikov National University (Voloshin, Olinchuk 2011). The procedure of the auditory analysis was performed in 6 stages.

The selection of the material took place at the first stage of the procedure. All the monologues with general duration of 50 minutes in whole were studied, and four most prominent abstracts illustrating the emotions of the character and referring to each age of Nemo, i.e. 9 , 16,34 and 118 years old were chosen for the further analysis.

The second stage opened with listening comprehension of the chosen extracts by 8 auditors - native speakers and experts in pronunciation and dividing each monologue into small sense groups. The main goal of the present stage consisted in:

- identifying the type of scale the protagonist speaks with and the semantic center of the monological unity;

- in marking stressed syllables;

- determining the nucleus syllable and its type (The Low Fall/The Rise Fall/The High Fall/ The Fall Rise).

The abstracts were listened to 3 times by the auditors and the results of the marking were put down into their auditory analysis cards.

On the third stage of the analysis each monologue was listened through 4 times, and Nemo Nobody's speech from the viewpoint of the following prosodic components was analyzed:

- Pitch level: (very) high/medium/(very) low) was to be determined.

- Loudness of speech: (very) loud/normal/ (very) low should have been identified.

- Tempo of speech with which Nemo pronounces his monologues was to be put down: (very) quick/normal/(very) slow.

The fourth stage of the auditory analysis implied identifying the type of emotion the protagonist 
experiences while pronouncing his monologues. The auditors selected the emotion from the list of emotions: thoughtful; meditating; regretful; sorrowful; confident; ambitious; disappointed.

The fifth stage consisted of checking out total results of the analysis of the prosodic peculiarities and putting them down into the tables (Auditory Analysis Cards) according to the number of the analyzed monologue. Eight auditors took part in the auditory analysis: 7 successful and 1 unsuccessful result were obtained. Evaluation and presentation of the auditory results were held in the following order: according to the auditory analysis arithmetical value of the quantitative estimation was calculated in marks by the next formula:

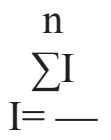

$\mathrm{m}$

where: I - is an arithmetical value of the estimation in marks; $m$ - is the amount of the auditors; $\mathrm{n}$ - for single evaluation by the auditors in marks (Voloshin, Olinchuk, 2011).

At the sixth stage the sum-total of the positive results was identified and final results calculated in percentage were put down in the table. The maximal and minimal values were characterized.

The sixth stage of the auditory analysis opens with the sum-total of the results given by the auditors and put down in the expert tables, where the type of prosodic components is marked. Thus, pitch level is divided into high, medium and low; loudness is distinguished as loud, normal and low; tempo of speech is divided into quick, normal and slow. Each monological unity (MU) is considered and analyzed separately, including stressed syllables, semantic centers and prosodic peculiarities. Remarks pointing at the psychological state of the protagonist at the moment of speech are put down by the auditors as well.
The next table (see Table 1) demonstrates the percentage proportion calculated from the results of the auditory analysis and reveals the dependency between the age of Nemo and the peculiarities of his speech.

Normal loudness is illustrative for the speech of little Nemo aged 9. He is still and not excited. The boy, thinking of the life choice, puts forward a hypothesis that everything remains possible until the right choice is made. Slow tempo of speech $(71 \%)$ in this monologue reveals the boy's thoughtfulness. He is deepened in his own meditations about the life choice.

The cues of the teenager (Nemo at the age of 16) are prominent for their maximal loudness, and syllables are pronounced on the low pitch level combined with the Low Fall only. Nemo sounds confident and ambitious. He is concentrated on his plans for future. The protagonist doesn't hurry while speaking, and pronounces every single syllable significantly, with the normal tempo and significant pauses.

According to the results from the table Nemo's speech at the age of 118 is characterized by a minimal loudness. It is mainly low and makes up $80 \%$ out of the whole. The minimal tempo of speech is typical for any elderly man in his years. He speaks slowly meditating on his actions and reconsidering his whole life. The maximal High pitch level typical for old Nemo reveals his depressed psychological state. He sounds regretful of the things he hasn't done during his youth. The idea of years passing away is manifested in the present monologue.

In order to prove or deny the put forward hypothesis the need to perform the electro-acoustic analysis of the selected monological units arose.

The electro-acoustic analysis was performed and accomplished within the PRAAT software in 5 stages. Pitch and Intensity ranges via the PRAAT computer program were observed.

The Final Results of the Auditory Analysis on Prosodic Peculiarities

Table 1 of Nemo Nobody's Speech Calculated in Percentage

\begin{tabular}{|c|c|c|c|c|c|c|c|c|c|}
\hline \multirow{2}{*}{$\begin{array}{c}\text { AGE } \\
\text { OF NEMO }\end{array}$} & \multicolumn{3}{|c|}{ PITCH LEVEL } & \multicolumn{3}{c|}{ LOUDNESS } & \multicolumn{3}{c|}{ TEMPO OF SPEECH } \\
\cline { 2 - 11 } & High & Med. & Low & Loud & Norm & Low & Quick & Norm & Slow \\
\hline 9 & $29 \%$ & $71 \%$ & $0 \%$ & $0 \%$ & $100 \%$ & $0 \%$ & $0 \%$ & $29 \%$ & $71 \%$ \\
\hline 16 & $7 \%$ & $0 \%$ & $93 \%$ & $93 \%$ & $7 \%$ & $0 \%$ & $0 \%$ & $100 \%$ & $0 \%$ \\
\hline 34 & $0 \%$ & $100 \%$ & $0 \%$ & $0 \%$ & $100 \%$ & $0 \%$ & $55 \%$ & $45 \%$ & $0 \%$ \\
\hline 118 & $60 \%$ & $0 \%$ & $40 \%$ & $0 \%$ & $20 \%$ & $80 \%$ & $0 \%$ & $0 \%$ & $100 \%$ \\
\hline
\end{tabular}


According to the results of the phonetic experiment the pitch varies from $200 \mathrm{~Hz}$ to $220 \mathrm{~Hz}$ thus indicating the fact that the protagonist speaks easy, no protruding emotions are traced in his remarks. He sounds monotonous and neutral. Syllables of the monologue under analysis are pronounced with the Middle Level Scale, no expressive final tones are employed.

Intensity presented varies greatly from its minimal point of $10 \mathrm{~dB}$ to its highest point of $60 \mathrm{~dB}$. The least values of the curve of $10 \mathrm{~dB}$ and $35 \mathrm{~dB}$ reveal the subsidence of the boy's voice when he pauses to meditate on life choice. The most meaningful phrases ("It's forever" and "As long as we don't choose - everything remains possible") are made manifest. They coincide with maximum peaks of voice loudness and are patterned on the points of $40 \mathrm{~dB}$ and $60 \mathrm{~dB}$. The speaker sounds enthusiastic, cheerful, and buoyant. The average intersyntagmatic space makes up $3.3 \mathrm{sec}$, which points at the slow tempo of speech. The boy drawls his words as it is typical for every child of his age.

In the next extract from Nemo's speech at the age of 16 he sounds confident and ambitious aiming to reach success in his future career. The pitch value attains $100 \mathrm{~Hz}$ thus registering the Middle Level Scale the protagonist speaks with. His voice doesn't fluctuate to a great manner, on the contrary it remains still and reserved. The intensity curve illustrates the variety of loudness from $40 \mathrm{~dB}$ to $60 \mathrm{~dB}$, which points out a stable emotional state of Nemo the teenager, who is concentrated on the idea of financial prosperity. It is only in the beginning when the boy speaks in a low voice $(40 \mathrm{~dB})$, thus collecting himself and preparing for saying something relevant. The average intersyntagmatic space is $1.5 \mathrm{sec}-$ the speaker sounds optimistic and pronounces his words in a quick tempo.

The next monologue under review demonstrates the feelings of old Nemo. Nemo aged 118: "I'm not afraid of dying. I'm afraid I haven't been alive enough. It should be renown - every schoolroom blackboard. Life is a playground. Or nothing". The Fundamental frequency makes up $60 \mathrm{~Hz}$, thus indicating the old man's frustration. He regrets about the years which ran through so quickly. Nemo has become too old for all life pleasures. He sounds thoughtful, monotonous, depressed. The speaker pronounces his monologue with the Low Level Head. The Intensity level constitutes $40 \mathrm{~dB}-50 \mathrm{~dB}$, thus revealing to the audience a low voice of the old man. He has no reason to cry out his plans on future as it took place in the monologue 2 . The youth time has already passed by, and he has become unable to realize them. It is regret and disappointment traced in the present extract. The intersyntagmatic space riches $4 \mathrm{sec}$ thus indicating at the slow tempo of the protagonist's speech.

To sum up the aforesaid it should me mentioned that Nemo's speech at the age of 34 and 118 attains minimal pitch value of $35 \mathrm{~Hz}$ and $60 \mathrm{~Hz}$ correspondingly.

Maximal pitch value makes up $220 \mathrm{~Hz}$ and characterizes little Nemo's speech at the age of 8 as expressive, emotional. The boy is curious about everything what is going around him. He sounds curious, observant and makes up his own conclusions about the surrounding world. According to the activity and valence scale introduced by linguist Scherer, Nemo's emotions are active, positive.

Minimal intensity is traced in excerpts 1 and 3 and reaches $45 \mathrm{~dB}$. Being a child the protagonist sounds still in abstract 1 and speaks in a low voice as if trying to concentrate on his own meditations about the world and life system. Despite his young age Nemo concludes new amazing things for himself personally. His emotions are moderate, not protruding. In contrast to monologue 1 the extract 3 opens with the words of regret. Low intensity of $45 \mathrm{~dB}$ reveals old Nemo's sorrow and pain concerning the faded youth. According to their valence and activity, submitted by Scherer in his investigation of emotions and prosody, Nemo's emotions are characterized as negative and passive. He sounds regretful, disappointed, miserable, and depressive.

Maximal intensity of $60 \mathrm{~dB}$ demonstrates Nemo's speech at the age of 16 . Being active and positive in their activity and valence, the protagonist's emotions rich their apogee. Teen-age maximalism with its expressiveness and emotionality is traced in his speech.

\section{Conclusion}

The present work dedicated to the analysis of stylistic and prosodic markers of the protagonist's monological speech in a science fiction-drama "Mr. Nobody" being the material of the investigation allows us to draw the following conclusions.

Monologue is a prolonged talk or discourse by a single speaker, especially one dominating or monopolizing a conversation. The main function of the monologue embedded in the cinematic discourse lies in conveying a particular piece of information to the audience. The speaker's aim is to express his viewpoint on some situation and to make his attitude towards his words clear and meaningful to the addressee. 
Cinematic discourse is a multicode cognitive-communicative formation, a combination of various semiotic units in their inseparable unity that is characterized by the coherence, integrity, completeness and addressness.

The work deals with the analysis of the monologues pronounced by Nemo Nobody. Four most prominent monologues illustrating the protagonist's speech at different periods of his life, that is at the age of $9,16,34$ and 118 , were extracted as an experimental corpus for the investigation.

In the course of the phonostylistic analysis disclosing the stylistic and prosodic markers of the character's monological speech it was observed that the monologues pronounced by young Nemo at the age of 16 and by old Nemo at the age of 118 tend to be the most prominent.

From the viewpoint of stylistics the abstracts abound in the variety of stylistic devices belonging to different linguistic levels. At this stage Nemo's speech is rich in the use of parallel constructions, lexical and syntactical repetitions, climax and other stylistic devices that add to the emotionality of the speaker. The devices involved in the extracted fragments serve as the characteristic feature of the protagonist and his temper.

In the course of the investigation it was found out that little Nemo tends to be more thoughtful and reasonable, whereas Nemo-teenager is ambitious and aims to achieve success in his future life. The cues of mature Mr. Nobody are rich in terminology and characterize the protagonist as a responsible anchorman, who concentrates his attention on his work only. Nevertheless, the old man's speech is more emphatic due to the application of the stylistic device of anticlimax ("I'm afraid I haven't been alive enough. Life is a playground. Or nothing") and key-words employed in his monologue (dying, alive, life). The extracted fragments abound in parallel constructions, lexical repetition, asyndetic types of connection which add to their expressiveness.

The research employed not only the stylistic means of expression but included the investigation of the prosodic components of pitch level, loudness and tempo. Within the auditory analysis these components revealed the essence of the chosen topic and proved the hypothesis of the correlation of the protagonist's age, his psychological state, his emotions and the peculiarities of his speech.

Slow tempo $(71 \%)$ is illustrative for the speech of little Nemo. He is calm and not excited. The boy, thinking of the life choice, puts forward a hypothesis that everything remains possible until the right choice is made. Slow tempo reveals the boy's thoughtfulness. He is deepened in his own meditations.

The cues of Nemo the teenager are prominent for their maximum loudness. Nemo sounds confident and ambitious. He is concentrated on his plans on future.

The speech of Nemo aged 34 is prominent for its maximal tempo. It indicates Nemo's concentration on his job of television anchorman which purports responsive attitude towards his work, because his main goal is to reach the attention of the audience. He doesn't have to be worried or to doubt. On the contrary, he should sound authoritative and informative in order to interest the audience and to persuade them in his words.

The speech of the old man is characterized by minimum loudness. The minimum tempo of speech is typical for any elderly man. He speaks slowly, meditating on his actions and reconsidering his whole life. The maximum high pitch level typical for old Nemo reveals his depressed psychological state. He is regretful of the things he hasn't done during his youth. The idea of years passing away is made manifest.

The electro-acoustic analysis accomplished in last part of the experiment reveals Pitch and Intensity values of Nemo Nobody's speech. Thus minimum pitch values are typical for Nemo aged 118 and 34 in the monologues 3 and 4 correspondingly. While recollecting his youth the protagonist sounds depressed and disappointed pronouncing the present cue with the Low Level Head. The pitch value reaches $60 \mathrm{~Hz}$ here. At the age of $34 \mathrm{Nemo}$ the anchorman delivers cognitive scientific information to the audience. Speaking with the Low Level Scale and the pitch of $35 \mathrm{~Hz}$ the man demonstrates his professionalism and confidence in the field of television discourse.

The maximum pitch value makes up $220 \mathrm{~Hz}$ and characterizes little Nemo's speech at the age of 8 . He sounds curious and observant.

The minimum intensity and minimum tempo of speech are traced in the monologues of little Nemo at the age of 8 and old Nemo at the age of 118 constituting $45 \mathrm{~dB}$ and wide intersyntagmatic space of $3.3 \mathrm{sec}$. And if in the first case it can be explained from the viewpoint of human physiology when the intensity and tempo of child's normal speech are low naturally, then in the second case the speech of the old man with its minimal intensity and minimum tempo demonstrates his depressed emotional state. 
The maximum intensity of $60 \mathrm{~dB}$ is observed in monologue 2 of Nemo the teenager when his feelings reach the emotional apogee and he says out loud plans on his future life and career. The pitch value in the present monologue attains it maximum point of $100 \mathrm{~Hz}$. Pronouncing every single word with the Middle Level Scale, the protagonist sounds reserved and self-assured.

The maximum tempo of speech with narrow intersyntagmatic space of $1.5 \mathrm{sec}$. is observed in the monologues of Nemo the teenager and 34-year-old Nemo, where the protagonist speaks confidently, expressively, emphasizing the most relevant events.

The put forward hypothesis concerning the correlation between the emotional state of the protagonist and stylistic-prosodic arrangement of his speech was proved in the course of the investigation, which allowed us to conclude that the age of the man has a direct impact on his style of speech, and emotionality of his words is dependent on the psychological state in which he occurs to be at the moment of speech. Age and emotions determine expressivity and prominence of the speaker's monologues in prosodic and stylistics parameters.

In perspective it is planned to extend the experimental corpus of the investigation, to expand the spectral analysis of the chosen extracts and to analyze extralinguistic peculiarities of the protagonist's speech.

\section{BIBLIOGRAPHY:}

1. Кухаренко В.А. Интерпретация текста. Одесса : Латстар, 2002. 289 с.

2. Лавриненко И.Н. Критерии классификации кинодискурса. Вісник Харківського національного універсиmету ім. В.Н. Каразіна. Серія «Романо-германська філологія. Методика викладання іноземних мов». 2012. № 1003. Вип. 70. С. 41-44.

3. Методы обработки результатов экспериментальнофонетических исследований речи и их лингвистическая интерпретация / В.Г. Волошин, Н.Р. Григорян, Е.М. Музя, В.В. Олинчук. Одесса : ВМВ, 2011. 186 с.

4. Chatman S. Story and Discourse: Narrative Structure in Fiction and Film. Cornell University Press, 1978. 288 p.

5. Praat Doing Phonetics by Computer / version 4.2. URL: http://praat.org/ (дата звернення: 21.08.2020).

6. "Mr. Nobody" Production Jaco Van Dormael. PanEuropéenne film Belgium, 2009. $141 \mathrm{~min}$.

\section{REFERENCES:}

1. Kukharenko V.A. (2002). Interpretatsiya teksta [Interpretation of text]. Odessa: Latstar. 289p.

2. Lavrinenko I. N. (2012). Criterion of classification of cinemadiscourse // Visnik Kharkivskogo Natcionalnogo ynivesiteta im. Karazina. (2012). № 1003. Vipysk 70. P. 41-44.

3. Methodi obrabotki resultatov eksperimentalno foneticheskih isledovanii rechi I in lingvisticheskoy interpretacia / Voloshin V.G., Grigorian N.R., Muzya E.M, Olinchuk V.V. Odessa : BMB, 2011. 186 p.

4. Chatman, S. Story and Discourse: Narrative Structure in Fiction and Film. Cornell University Press, 1978. 288 p.

5. Praat Doing Phonetics by Computer / version 4.2. URL: http://praat.org/.

6. "Mr.Nobody" Production Jaco Van Dormael. PanEuropéenne film Belgium, 2009. $141 \mathrm{~min}$.

Стаття надійшла до редакиії 09.10.2020. The article was received October 9, 2020. 